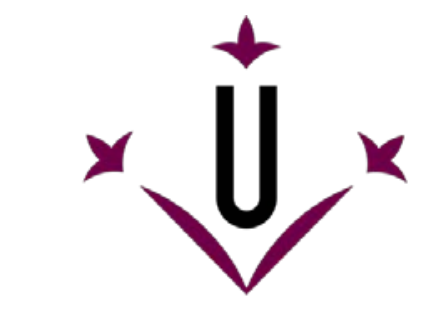

Universitat de Lleida

Document downloaded from:

http://hdl.handle.net/10459.1/65065

The final publication is available at:

https://doi.org/10.1007/s10722-012-9831-9

Copyright

(c) Springer Verlag, 2013 


\title{
Whole-genome analysis with SNPs from BOPA1 shows clearly defined groupings of Western Mediterranean, Ethiopian, and Fertile Crescent barleys
}

Ernesto Igartua ${ }^{1,4}$, Marian Moralejo ${ }^{2}$, Ana María Casas ${ }^{1}$, Lluís Torres ${ }^{2,3}$, and José-Luis Molina$\mathrm{Cano}^{2}$

${ }^{1}$ Estación Experimental de Aula Dei-CSIC (EEAD-CSIC), Avda Montañana 1005, 50059

Zaragoza, Spain

${ }^{2}$ Centro Universitat de Lleida-Institut de Recerca i Tecnología Agroalimentàries (UdL-IRTA), Rovira Roure 191, 25198 Lleida, Spain

${ }^{3}$ deceased

${ }^{4}$ Corresponding author: igartua@eead.csic.es

\begin{abstract}
The discovery of Hordeum spontaneum C. Koch, a wild ancestor of cultivated barley, in Morocco in 1978 led to the proposal of a multicentric origin for this crop, as an alternative to the widely accepted theory of a single centre of domestication in the Fertile Crescent. Since this discovery, we have tested this hypothesis using the most advanced genetic techniques available at the time, from CM-proteins to RFLP and DNA-chloroplast markers. Nowadays, the availability of single nucleotide polymorphism (SNP) markers that are spread densely over the barley genome provides us with another powerful tool to give further support for the above. We have used 1,536 SNPs from the Barley Oligo Pool Assay 1 (BOPA1) of Illumina to characterize 107 wild and cultivated barley accessions from the Western Mediterranean, Fertile Crescent, Ethiopia, and Tibet. The results have confirmed that each location of the above-mentioned germplasm groups clusters separately. Analysis of molecular variance enabled us to focus on the chromosomal regions and loci that differentiated these groups of barley germplasm. Some of these regions contain vernalization and photoperiod response genes, some of the so-called domestication genes, as well as the most important quantitative trait locus for flowering time in the Mediterranean region. We have combined these results with other genetic evidence, and interpreted them in the framework of current theories on the onset of the Neolithic revolution in the Mediterranean region, to conclude that neither Ethiopia nor the Western Mediterranean can be ruled out as centres of barley domestication, together with the Fertile Crescent.
\end{abstract}

\section{Key words}

Barley, domestication, phylogeny, Western Mediterranean, whole-genome scan 


\section{INTRODUCTION}

In 1926, Vavilov defined the centre of origin of a crop as the region where the greatest genetic diversity is found and wild and cultivated species coexist (cf. Harlan 1992). Since then, the centre of origin of barley has been debated widely, although the majority of researchers continue to support the Fertile Crescent as the only location which it was domesticated (review in Molina-Cano et al. 2002).

More recently, the debate about the centre of origin of barley has centred on whether the socalled founder crops (einkorn wheat, Triticum monoccocum L.; emmer wheat, T. turgidum L.; barley, Hordeum vulgare L.; lentil, Lens culinaris Medikus; pea, Pisum sativum L.; chickpea, Cicer arietinum L.; and bitter vetch, Vicia ervilia (L.) Willd.) have a monophyletic or polyphyletic origin inside or outside the Fertile Crescent, and whether domestication is a diffuse or rapid process (reviews in Willcox 2005; Weiss et al. 2006; Allaby et al. 2008; Brown et al. 2008; Purugganan and Fuller 2009; Abbo et al. 2010; Gross and Olsen 2010). Given the multiple archaeological excavations that have taken place in the Fertile Crescent region, the archaeobotanical record has been presumed to contribute superior evidence to that of the genetic approach. This is due to the fact that the latter approach is based on samples from currently living populations, which cannot be dated with ${ }^{14} \mathrm{C}$ in contrast to archaeobotanical remains (Abbo et al. 2010).

Hordeum spontaneum C.Koch, the wild ancestor of cultivated barley, was discovered in Morocco in the mountain pass Tizi-n-Taghatine, which is close to the Djebel Siroua range (Molina-Cano and Conde 1980). A second collection trip in 1980 led to the discovery of 25 additional populations of the species (Molina-Cano et al. 1982). The plants were identified conclusively as $H$. spontaneum by two of the leading authorities on barley phylogeny at the time (F.Kh. Bakhtheyev, personal communication; J.R. Harlan, personal communication).

Work on these populations of $H$. spontaneum has been progressing for more than 30 years, and has included the use of the best genetic markers available at the time, such as CM-proteins (chloroform-methanol soluble proteins) and agromorphological traits (Molina-Cano et al. 1987), RFLPs (Molina-Cano et al. 1999), and chloroplast-DNA SSRs (Molina-Cano et al. 2005). The results have always shown clear-cut genetic differences between the Moroccan H. spontaneum and both wild and cultivated barleys with other non-Western Mediterranean origins.

The identification of a centre of origin for barley in the Western Mediterranean on the basis of our results has been criticized by some researchers (e.g. Badr et al. 2000; Blattner and Madani- 
Méndez 2001; Salamini et al. 2002). In addition, the existence of $H$. spontaneum in Morocco has been attributed to a back mutation in cultivated barley (e.g. R. von Bothmer, personal communication). This is unlikely, because $H$. spontaneum is two-rowed, but $80 \%$ of Moroccan barley is six-rowed (H Bockelman, pers. comm.), and the populations cultivated in the region of collection are all six-rowed. A back mutation would imply that two natural events had occurred: 1) a change from six- to two-rowed and 2) a change from a tough to a brittle rachis. Both of these changes involve the shift from a recessive to a dominant allele of a gene and the first involves a change from lack of function to function (Komatsuda et al. 2007). This combination of events seems extremely unlikely, especially given that the probability of either of these independent mutations occurring is less than $10^{-5}$ (N. Jouve personal communication), which would give a probability of both occurring simultaneously of around $10^{-10}$.

Furthermore, the archaeobotanical record of the Central Sahara is very limited compared with that of the Fertile Crescent region. As a consequence, it would be critical to prove the existence of wild barley in the Central Sahara before the Sahara dried out from the third millennium BC onwards (reviews in Muzzolini 1989, Harlan 1992) to establish a link between barley domestication in Ethiopia and North Africa from an archaeological perspective, especially as this relationship has already been indicated from the available genetic evidence (Molina-Cano et al. 2005, data presented herein). An interesting approach to the topic of North African Neolithic was pointed out by Muzzolini (1989), who argued that it followed a different pattern from that of the Fertile Crescent.

In summary, the discovery of $H$. spontaneum in sites other than the Fertile Crescent, such as Tibet, Morocco, Libya, Egypt, Crete, and Ethiopia (reviewed in Molina-Cano et al. 2002), has challenged the prevalent monocentric theory on the origin of barley. With respect to the number of domestication events, there are an increasing number of researchers who claim at least a diphyletic origin, either inside or outside the Fertile Crescent (e.g. Takahashi 1955; Zohary 1999; Willcox 2005; Komatsuda et al. 2007; Morrell and Clegg 2007; Orabi et al. 2009; Bjørnstad and Abay 2010).

Our aim here was to continue the work of the last 30 years by applying the latest generation of molecular markers (1,536 SNPs from the BOPA1 platform) in an attempt to cast more light on the origin of barley.

\section{MATERIAL AND METHODS}

\section{Plant material}


The barley material studied (Table 1; Supplementary Table 1) included a representative sample of cultivated barleys from the Western Mediterranean-North Africa (WM), namely accessions from Morocco, Libya and Spanish criolla (creole) types (descended from Spanish landraces brought to Bolivia in the 15th-16th centuries); Ethiopia (ETH); H.spontaneum (HSP) from Morocco, Ethiopia, Israel, Turkey, Afghanistan, Iran, Crete, Cyprus, Libya, and Iraq; and, finally, Hordeum agriocrithon E. Åberg (AGR) from Tibet (including some of the accessions studied by Konishi 2001). Most of the material included has already been studied using chloroplast-SSRs (Molina-Cano et al. 2005), and we wanted to confirm the results obtained previously. A total of 107 accessions were used in this study, but complete results were only obtained for 103 of them owing to missing data for four entries.

\section{Molecular methods}

Genomic DNA was extracted from one individual plant of each accession. The 107 accessions were genotyped for 1,536 single nucleotide polymorphisms (SNPs) using the Barley Oligo Pool Assay 1 (BOPA1) of Illumina (Close et al. 2009) at the Southern California Genotyping Consortium. Of the original allele calls, AA was coded as $1, \mathrm{BB}$ as 0 , and heterozygous data were converted to missing values. Monomorphic SNPs or those with more than $20 \%$ missing values were removed, which left 1015 SNP loci. A subset of 357 SNPs was selected to classify the accessions, using the following approach. Markers with an unknown map position, with more than $10 \%$ missing data, or with a minimum allele frequency of less than 0.05 were excluded. From the remaining markers, evenly spaced markers at a distance of at least $1 \mathrm{cM}$ were selected. To generate a complete data set, $3.55 \%$ of the data, which were missing, were imputed on the basis of the closest SNP markers. To justify the use of BOPA1 platform in material other than cultivars, we want to quote Russell et al. (2011): ...further research on origins will need to extend the use of the BOPA1 assay to geographically matched landraces and wild accessions collected from throughout the Fertile Crescent...

\section{Statistical methods}

Principal component analysis (PCA) and Ward clustering were carried out with JMP V8.0.1 (JMP, SAS Institute, Cary, NC, USA, 2008) using the 357 SNP subset with no missing data. The hierarchical clustering method of Ward begins with $t$ separate operational taxonomic units (OTUs), groups them successively into $\mathrm{t}-1, \mathrm{t}-2, \ldots, 1$ taxa, and at each stage computes a socalled objective function, which is the sum of the within groups sum of squares (Sneath and Sokal 1973). 
Neighbour-joining clustering on a Jaccard dissimilarity matrix, with 10,000 bootstraps to evaluate the reproducibility of nodes, was carried out with DARwin5 (Perrier and JacquemoudCollet 2006).

The groups of genotypes defined by the clustering procedures were used to assess genome-wide diversity. For this purpose, the original data set of 1015 SNPs was used. The structure of genetic diversity within and among groups was examined through analysis of molecular variance (AMOVA) using Arlequin 3.5 (Excoffier and Lischer 2010). The frequency of missing data allowed in the analysis was 0.15 . Contrasting patterns of genetic diversity within and between groups were also used to detect loci under selection, using the hierarchical island model, with the same software. To detect loci under selection, for the WM, HSP, and ETH groups, we followed the procedure provided by Arlequin, which performs pairwise comparisons of genetic diversity ('heterozygosity') and differentiation (FST) within and between groups. The differentiation between populations or groups (FST) for each locus is then compared with the values expected under neutrality, and outliers are detected. These outliers are interpreted as loci under selection. The expected FST values must be calculated following a given demographic model. We have followed the method put forward by Excoffier et al. (2009), using the hierarchical island model. This method reduces the occurrence of false positives in the detection of outliers. The loci identified by this method may have been subjected to either balancing or diversifying selection. The results are expressed as $-\log _{10}$ of the probability associated with its FST value. This figure expresses the probability that such an FST value is expected in the absence of selection. We present only the results for loci under diversifying selection, that is, loci that may have experienced shifts in frequencies owing to distinct selection agents acting at different geographical regions. Balancing selection is not applicable to these data, because the individuals are not breeding populations but rather isolated lines.

\section{RESULTS}

\section{Grouping of germplasm}

PCA grouped the accessions into three defined groups [ETH (Ethiopia), WM (Western Mediterranean-North Africa), and HSP (H. spontaneum from regions other than Morocco)] in a space determined by the three first principal axes, which accounted for $38 \%$ of total variance (Fig. 1). Some entries were placed in between the three main clusters; they formed a mixed group that comprised cultivated barleys from WM and ETH, $H$. agriocrithon, and an accession 
of $H$. spontaneum from Cyprus. Similar groups were also formed by neighbour-joining analysis (Supplementary Fig. 1).

The cluster analysis with the Ward method (Fig. 2) also confirmed, in more detail, the four groups described above. The cluster WM neatly separated the large majority of the materials from the Western Mediterranean and North Africa from the rest of the accessions. The WM cluster contained three subgroups; the largest one included barleys from Morocco and Libya, and Spanish criolla entries. A second subcluster contaied the Moroccan H. spontaneum, together with two two-row Moroccan cultivated barleys (PI 356226 and CIho 3181, Esperance). A third subcluster included six entries of Moroccan cultivated barley together with a $H$. spontaneum from Cyprus.

The ETH cluster included cultivated and wild Ethiopian barleys, as well as three Moroccan cultivated barleys that corresponded to entries PI 356711 (six-row normal kernel), PI 356713 (six-row black kernel), and PI 356715 (two-row deficiens type and dark kernel, H. vulgare convar. deficiens (Steud.) Mansf. ), with the latter two being of typical Ethiopian phenotype.

The HSP cluster was formed by H. spontaneum accessions from regions other than Morocco, and was separated clearly from the other groups.

The mixed group (AGR) contained two subclusters: the first comprised all the H. agriocrithon Tibetan entries, together with an $H$. spontaneum from Afghanistan and a Spanish criolla, whereas the other consisted of three Ethiopian entries plus a Spanish criolla and a $H$. spontaneum from Afghanistan. Four of the H. agriocrithon Tibetan entries (HOR 2268, HOR 2456, HOR 2465, and HOR 2466) were identical with respect to all the BOPA1 markers.

\section{Analysis of molecular variance}

The clustering of accessions on the basis of the complete set of 357 SNPs revealed the basic structure of the germplasm that was then used for further analysis of genetic features with the complete set of 1015 markers.

The partitioning of genetic variance between and within groups was assessed by AMOVA, which showed that $42.1 \%$ of the variation was between groups (Table 2). The SNP markers employed can differentiate between these groups of accessions. Individual comparisons for each pair of groups revealed that ETH was the most distinct group, with FST values higher than 0.50 
upon comparison with WM or HSP, whereas the mixed AGR group was the least distinct (Table $3)$.

\section{Detection of loci under selection - Patterns of polymorphism along barley chromosomes}

The probability that loci had undergone selection was calculated for all loci individually, but we only present the results for SNPs with a known position in the consensus map (Close et al. 2009). Fig. 3 shows the scans of heterozygosity (or gene diversity) for pairs of the germplasm groups considered, as well as the - $\log _{10}$ of the probability that loci were subjected to selection, for WM-HSP, WM-ETH, and HSP-ETH. The values were averaged across a sliding window of 21 adjacent loci (10 above and 10 below a certain SNP) with a step of one and plotted against the linkage map. Average diversity was higher in WM and HSP ( 0.23 and 0.21 , respectively) than in the group of Ethiopian barleys (average 0.12). This was more evident along chromosomes $3 \mathrm{H}$ and $5 \mathrm{H}$, where many loci were almost fixed in the ETH group. The overall diversity found in the groups was affected by the different sample sizes. For this reason, it was even more remarkable that the lowest diversity was detected on the long arm of chromosome $7 \mathrm{H}$ in $\mathrm{WM}$, the largest group. Although overall heterozygosity was low for ETH, there were regions of high diversity for this group, compared to the others, in most chromosomes.

Examination of the profiles shown in Fig. 3 reveals highly variable patterns of heterozygosity across the genome for all germplasm groups. Comparisons of the distributions of heterozygosity and FST values point to regions that may contain loci under selection (Fig. 3). The genomic regions that were most likely to be under selection were those characterized by low diversity in at least one of the two groups in each comparison, together with a peak for the probability of 'loci under selection'. We chose a threshold of 1.3 for the moving averages of the $-\log _{10}(\mathrm{P})$ value of the FST, which corresponds to a $\mathrm{P}$ value of 0.05 . Below, we describe the regions that were likely to be under selection for the three comparisons.

\section{Western Mediterranean - Hordeum spontaneum}

In the comparison of WM and HSP, we identified three chromosomal regions that showed some evidence of selection. In the first one, on chromosome $5 \mathrm{H}$ (approximately $51.0-51.6 \mathrm{cM}$ ), the WM group showed several loci that were almost fixed, whereas there was more diversity in HSP. In the second region, on $6 \mathrm{H}$ (around 55-59 cM), there was a reduction in diversity in both groups but different alleles were fixed in each group. In particular, at $55.7 \mathrm{cM}$, there were four loci that were almost fixed in the WM group. The last region, on $7 \mathrm{H}(77.9-86.4 \mathrm{cM})$, 
corresponded to a broad reduction in diversity in the WM group and there were contrasting alleles at a number of SNPs in both groups.

\section{Western Mediterranean - Ethiopia}

In the comparison of the WM and ETH groups, we identified three regions with some evidence of differentiation. The first was on chromosome 1H (92.8-101.4 cM) and showed low diversity in both groups. Around 92.9-99.9 cM, there were several SNPs that showed contrasting alleles. The second region was on chromosome 5H (129.4-137.2 cM), and was associated with low diversity in ETH. There were 16 loci in this region that were fixed in the ETH group, whereas some diversity was found in the WM group. The third region was on $7 \mathrm{H}(62.9-71.1 \mathrm{cM})$, and showed low diversity and contrasting alleles in both groups compared.

\section{Ethiopia - Hordeum spontaneum}

The comparison of ETH and HSP revealed regions that showed differentiation between the two groups on all chromosomes. Sixteen regions were identified. This large number of regions was a consequence of the low overall diversity of the ETH group. The regions were scattered over all the chromosomes. The most relevant features were the highest peak, found on the short arm of $6 \mathrm{H}$, the large region at $3 \mathrm{H}$ (which comprised most of the long arm), and the abundance of regions on $2 \mathrm{H}$ and $5 \mathrm{H}$.

\section{DISCUSSION}

Genome-wide analysis of SNP markers divided the tested accessions into four groups. The three most distinct groups were built around the Ethiopian landraces, Middle Eastern $H$. spontaneum, and Western Mediterranean wild and cultivated barleys, respectively. This classification confirmed previous results that were obtained using chloroplast or genomic SSRs (Molina-Cano et al. 2005; Orabi et al. 2007). The differentiation and low diversity of Ethiopian barleys were also highlighted by Bjørnstad and Abay (2010). These researchers indicated that Ethiopian barleys form a very distinct group: they have unique diversity in terms of resistance to certain diseases and morphology, but their average diversity with respect to DNA markers or nucleotides is substantially less than that of barley from the Fertile Crescent, as found in other studies (Saisho and Purugganan 2007). 
The H. agriocrithon accessions (six-rowed with brittle rachis) that were included in our study did not cluster within any of the above-mentioned groups but were found in an intermediate position together with some Ethiopian and Western Mediterranean cultivated barleys. The intermediate classification of $\mathrm{H}$. agriocrithon accessions confirmed previous findings by Tanno and Takeda (2004), who found similar alleles in H. agriocrithon and six-rowed cultivated barleys at cMWG699, a diagnostic marker for domestication. They deduced that $H$. agriocrithon probably originated from hybridization between $H$. spontaneum and six-rowed cultivated barley. It is possible that Tibetan $H$. agriocrithon originated from natural hybridization between $H$. spontaneum and six-rowed barley from Northern Afghanistan, Pakistan, or India, after which seeds of their segregants were brought up to Tibet mixed into barley or wheat, and resulted in six-rowed barley with brittle rachis (Konishi 2001). In the current study, an Afghan H. spontaneum accession (PI 220523) clustered together with $\mathrm{f}$. agriocrithon entries (Fig. 2). Other example of natural hybridization between H. spontaneum and six-rowed barleys had been described also in Libya (Hammer et al, 1985).

The present results, obtained with a much larger set of markers than previous studies, though do not prove our polyphyletic hypothesis, provide further evidence supporting it. This is so because H. spontaneum from Morocco clustered together with cultivated barleys from the same region, but not with other $H$. spontaneum from the WANA (West Asia-North Africa) region, as previously reported by Orabi et al. (2009) using genomic SSRs. Since the identification of weedy wild barley stands in Morocco (Molina-Cano et al. 1982), the question of whether barley could have been domesticated in the North of Africa, in addition to the Fertile Crescent, has been the subject of much debate. Evidence to support (Molina-Cano et al. 1987, 1999, 2005) or contradict this hypothesis (Badr et al. 2000, Blattner and Badani-Méndez 2001) has been presented. The most recent evidence supports the presence of a genetic background specific to the Western Mediterranean region. The most relevant information comes from the interpretation of results on nucleotide variation at the cMWG699 locus (which encodes elongation factor G), and is linked closely to VRS1, the main locus that determines spike type in barley. The D haplotype of this locus was described by Tanno et al. (2002) and Baba et al. (2011) to be characteristic of the Western Mediterranean region, because it occurred only in some six-rowed and two-rowed barley accessions from North Africa and in Moroccan wild barley. Tanno et al. (2002) interpreted the distribution of haplotypes for this gene across germplasm groups as indirect evidence to support the multiple origin hypothesis for six-rowed barley. Baba et al. (2011) suggested a Moroccan parentage for European six-rowed barleys that have the D allele at that locus. The results of our group have demonstrated that the D haplotype is actually widespread among six-rowed Spanish landraces and commercial varieties from Central Europe (Casas et al. 2005). It is also found in some two-rowed landraces that originated from Spain and 
Morocco. Phylogenetic analysis after the isolation of VRS1 (Komatsuda et al. 2007) demonstrated that the origin of the six-rowed phenotype was probably polyphyletic with origins at different times and locations, and occurred via a series of independent mutations at the VRS1 locus. The authors identified a six-rowed allele, vrs1.a2, which predominates in the Western Mediterranean and probably originated locally from the Vrs1.b2 allele. Again, these findings confirm the distinctive genetic characteristics of Western Mediterranean barleys. A definitive proof to settle the questions open about barley domestication will soon be technically feasible at reasonable cost, with a combination of the advances in next generation sequencing techniques and a carefully chosen set of wild and cultivated barley from all genetically distinct areas of their worldwide distribution. In any case, this approach will have to bear in mind the influence of gene flow between wild populations and cultivated forms, as recently demonstrated by Hübner et al. (2012).

In addition to the appearance of the six-rowed spike, the brittle rachis character is considered to be a major domestication event in barley (Sakuma et al. 2011), although the genes involved have not been isolated yet. Azhaguvel and Komatsuda (2007) have analysed polymorphism in a DNA sequence linked closely to the brittle rachis complex in a collection of cultivated barleys, wild barleys, and weedy brittle rachis varieties (H. agriocrithon). In a phylogenetic tree, the western (btr1-carrying; W-type) and eastern (btr2-carrying; E-type) cultivars clustered separately. Some of the Tibetan H. agriocrithon lines were related closely to the E-type and others to the W-type of cultivated barleys, which again suggested the hybrid origin of Tibetan H. agriocrithon. Two Moroccan wild barleys were also included in this study; they were completely homologous to some of the E-type cultivars. The authors stated that, although there may be a close relationship between Oriental and North African barley, it is difficult to argue that North African wild barley was the immediate ancestor of the modern E-type cultivars. They suggested that gene flow had resulted in Western Mediterranean cultivars and North African wild barleys sharing alleles that were specific to those regions. Indeed, they concluded that the North African wild barley lines may be in a taxonomical situation that is similar to that of Tibetan H. agriocrithon.

The patterns of selection footprints that were obtained from the pairwise comparisons of the groups were less clear-cut than those obtained in studies that used less diverse germplasm (Comadran et al. 2011a). All the regions of selection that were identified showed low diversity in at least one of the groups compared (most frequently, in both groups) and different predominant alleles at several SNPs. 
The different sample sizes among the groups prevent definite conclusions being drawn from the selection footprints. Nevertheless, some interesting trends are apparent from the comparison of SNP frequencies across the groups. It is remarkable that several regions that are apparently under selection contain loci that are associated with either the domestication process or the adaptation of the crop to geographical areas and agricultural systems. For example, on chromosome $1 \mathrm{H}$, there were two regions that appeared to contain loci under selection, one on each side of the centromere. The region on the long arm corresponded to the region of PpdH2. $\mathrm{PpdH} 2$ is one of the most important determinants of flowering time in Mediterranean climates (Boyd et al. 2003; Cuesta-Marcos et al. 2008). Three markers that were located at a position very similar to the one determined by Cockram et al. (2011) and Comadran et al. (2011b) to be the location of PpdH2, showed distinct alleles between the ETH and HSP. In addition, Bjørnstad \& Abay (2010) have suggested that Ethiopian barleys have a low level of diversity at this locus because most Ethiopian barleys carry the allele that is sensitive to short photoperiod. These findings support this gene being behind this selection footprint.

For $2 \mathrm{H}$, the comparison between WM and HSP revealed a peak in the region of Eam6 (52-59 $\mathrm{cM}$ ) that was just below the threshold level but very prominent locally. Five distinct selection signals were identified on $2 \mathrm{H}$ when ETH and HSP were compared, although this comparison involved the least number of accessions and, thus, the results were less reliable than those of the other comparisons. Despite this, it is remarkable that the peak around Eam6 was also the highest in the comparison of ETH and HSP. Eam6, together with PpdH2 is shown to be the most important gene in the determination of flowering time in Mediterranean climates. Several studies of quantitative trait loci (QTLs) have suggested that the allele that gives the fastest flowering response is advantageous in the Mediterranean climate. As a consequence, we might expect the allele for fast development to be fixed in accessions originally from the Mediterranean area. The region of $2 \mathrm{H}$ that contains Eam6 has been shown to contain major QTLs in several studies (Boyd et al. 2003; Castro et al. 2008; Cuesta-Marcos et al. 2008), and the gene responsible has been identified as Eam6. Several association mapping studies have identified SNPs in that region that are associated with differences in heading date (CuestaMarcos et al. 2010; Comadran et al. 2011b; Massman et al. 2011). Another region of selection on 2H (78-97 cM) may contain VRS1, which is the main gene for the determination of spike type in barley and one of the key genes associated with its domestication. The VRS1 locus coincided with the region of minimum diversity of the ETH group on this chromosome, which was also one of the regions of lowest diversity throughout the entire genome. Synthetic markers of the VRS1 gene have been localized at $87 \mathrm{cM}$ in a consensus map (Cuesta-Marcos et al. 2010). 
Chromosome $3 \mathrm{H}$ was remarkable for the extremely low diversity of the ETH group over most of the long arm. Other studies, most recently Comadran et al. (2011a), have found evidence of selection on $3 \mathrm{H}$, around the estimated position of the nonbrittle rachis loci (btr1/btr2), which is located at around 40-50 cM on the OPA consensus map (Close et al., 2009). The work by Comadran et al. (2011a) was carried out with elite material from UK and US breeding programmes and, in that case, the depression of diversity around btr1/btr2 was evident. In our study, the set of accessions is probably much more diverse, because it includes a high proportion of landrace material from several geographical regions. The fact that we found no selection footprint at this region is actually not surprising. As mentioned above, Komatsuda et al. (2004) and Azhaguvel and Komatsuda (2007) used markers linked closely to the btr genes to differentiate two main groups of barleys, the occidental (W) and oriental (E) types. The classification of the few accessions studied from Spain or North Africa was not clear-cut, but they were placed finally with the E group, in contrast with other western cultivated barleys, which are W-type. We do not know the allelic composition at the btr loci for most of our accessions, but we can speculate that they are a mixture of $\mathrm{E}$ and $\mathrm{W}$ accessions, which would impede the identification of a selection footprint by the method used.

Chromosome 4H showed a large region of low diversity in the HSP group, although we were unable to develop a possible explanation for this. The only peak $(26-55 \mathrm{cM})$ that indicated possible selection was identified in the ETH-HSP comparison, in the vicinity of the INTERMEDIUM-C or INT-C gene. The location of this gene, which was involved in the domestication process of barley (Pourkheirandish and Komatsuda 2007; Sakuma et al. 2011), has been identified recently with precision, and a candidate has been put forward by Ramsay et al. (2011). Distinct alleles were identified for several SNPs in the region $(26.2-28.4 \mathrm{cM})$ in the WM and ETH groups, although the peak that indicates the probability of loci under selection is just below the threshold chosen (1.26).

On $5 \mathrm{H}$, the most important region appeared to be the one around VRNH1 $(129-137 \mathrm{cM})$. A large peak was identified in the comparison between WM and ETH. Distinct alleles were identified for four SNPs in this region in the WM and ETH groups. One of these SNPs maps very close to VRNH1 (Casao et al. 2011). VRNH1 is one of the most important genes for the determination of growth habit in barley (Trevaskis 2010) and, together with VRNH2, separates the winter from the spring cultivars, and drives one of the most important classes in barley germplasm. As a consequence, it was expected that this gene would be the source of a conspicuous selection footprint. Other regions of selection on $5 \mathrm{H}$ were evident: around $51 \mathrm{cM}$ in the comparison between WM and HSP, and at $61-86 \mathrm{cM}$ in the comparison between ETH and 
HSP. Genes int- $b$ and vrs2, which are also involved in the domestication process, are located on the short arm of 5H (Cuesta-Marcos et al. 2010).

Chromosome $6 \mathrm{H}$ displayed a rather marked peak for selection at 55-59 $\mathrm{cM}$ in the WM-HSP comparison. In the ETH-HSP comparison, two peaks surrounded the location of the former peak. Although the locations of these peaks were not exactly the same, the approach used only allowed the positions to be estimated roughly, and we cannot rule out an identical location. However, we could not find any genes in this segment that might be responsible for the selection effect.

The central part of chromosome $7 \mathrm{H}$ exhibited a marked decrease in diversity in the WM group. Apparently, this group of accessions has been subject to selection pressure towards the fixation of alleles on this chromosome. As a consequence, selection footprints were apparent in the comparisons between this group and either HSP or ETH, although the positions were slightly different (78-86 cM and 63-71 cM, respectively). The range of SNPs affected, especially for the WM-HSP comparison, included several SNPs that were in common with the markers used by Druka et al. (2011) to genotype backcross mutants in the dense spike 1 (dsp1) gene. This gene has been proposed already by Komatsuda et al. (2004) as one of the factors that drove barley domestication, through interaction with the nonbrittle rachis btr genes on $3 \mathrm{H}$. Sameri et al. (2006) and Taketa et al. (2011) have mapped the $d s p 1$ gene to the region of the SNPs detected in the current study.

A possible role of ascertainment bias on our results cannot be ruled out. Ascertainment bias of this marker set in barley has been reported (Moragues et al. 2010). This set of SNPs was developed to capture diversity in a small set of modern cultivars (Rostoks et al. 2005) and some loss of diversity when used on landrace or wild barley materials can be expected. The main effect of ascertainment bias is a reduced power to detect recent population differentiation (Hübner et al. 2012), so the differences found in our study could actually be underestimated. Also, the concentration of differences on diversity in specific regions of the genome, and not at random, suggests the action of genetic forces. Genetic bottlenecks and drift and may be a possibility underlying the differences in diversity, but in situ adaptation is another plausible option.

\section{Closing Remarks}

The genetic diversity identified in this study confirmed previous results about the distribution of genetic diversity in barley germplasm. The advantage of the present analysis lies in the dense 
coverage provided, compared with that of previous studies, and also in the relevance of the markers themselves, because they are derived from genes and not from non-coding regions. Germplasm from the Western Mediterranean region and Ethiopia showed distinct genetic characteristics. We identified several regions with distinct allelic content among the groups. Some of these regions contain well-known genes for adaptation that may have been the target of the selection forces that shaped the distribution of genetic diversity in barley. Two of the chromosomal regions detected, around PpdH2 on $1 \mathrm{H}$ and Eam6 on $2 \mathrm{H}$, also appeared to be involved in the differentiation of germplasm from the Mediterranean area from that of other groups; these genes are well known as determinants of the main flowering time in the Mediterranean area (Boyd et al. 2003; Cuesta-Marcos et al. 2008). Furthermore, the results described herein favour our hypothesis of a polyphyletic origin for cultivated barley, with additional centres of origin in the Western Mediterranean and Ethiopia, apart from the widely accepted Near-Eastern centre.

\section{Acknowledgements}

We want to thank INIA (MICINN) for partially funding this work through different grants. The Centre UdL-IRTA forms part of the Centre CONSOLIDER on Agrigenomics funded by the Spanish Ministry of Education and Science and acknowledges partial funding from grant AGL2005-07195-C02-02. Genotyping of the RIL population with BOPA1 was funded by the Spanish Ministry of Science and Innovation; project GEN2006-28560-E. We thank Prof. Nicolás Jouve Universidad de Alcalá de Henares, Spain) for supplying us with interesting information regarding mutation frequencies. We also thank Dr. Helmut Knüpffer (IPK, Gatersleben, Germany), who kindly supplied us with the Hordeum agriochrithon accessions.

\section{References}

Abbo S, Lev-Yadun S, Gopher A (2010) Agricultural origins: Centers and Noncenters; a Near Eastern reappraisal. Critical Rev Plant Sci 29: 319-328

Allaby RG, Fuller DQ, Brown TA (2008) The genetic expectations of a protracted model for the origins of domesticated crops. Proc Natl Acad Sci USA 105: 13892-13896

Azhaguvel P, Komatsuda T (2007) A phylogenetic analysis based on nucleotide sequence of a marker linked to the brittle rachis locus indicates a diphyletic origin of barley. Ann Bot 100: 1009-1015

Baba T, Tanno K, Furusho M, Komatsuda T (2011) Allelic variation at the EF-G locus among northern Moroccan six-rowed barleys. Plant Genetic Resources: Characterization and Utilization. 9: 240-242

Badr A, Müller K, Schäffer-Pregl R, El Rabey H, Effgen S, Ibrahim HH, Pozzi C, Röhde W, Salamini F (2000) On the origin and domestication history of barley (Hordeum vulgare ) Mol Biol Evol 17: $499-510$ 
Bjørnstad A, Abay F (2010) Multivariate patterns of diversity in Ethiopian barleys. Crop Sci 50: 15791586

Blattner FR, Badani-Méndez A (2001) RAPD data do not support a second centre of barley domestication in Morocco. Gen Res Crop Evol 48: 13-19

Boyd WJR, Li CD, Grime CR, Cakir M, Potipibool S, Kaveeta L, Men S, Kamali MRJ, Barr AR, Moody DB, Lance RCM, Logue SJ, Raman H, Rea BJ (2003) Conventional and molecular genetic analysis of factors contributing to variation in the timing of heading among spring barley (Hordeum vulgare L.) genotypes grown over a mild winter growing season. Aust J Agric Res 54: 1277-1301

Brown TA, Jones MK, Powell W, Allaby RG (2008) The complex origins of domesticated crops in the Fertile Crescent. Trends Ecol Evol 24: 103-109

Casao MC, Igartua E, Karsai I, Bhat PR, Cuadrado N, Gracia MP, Lasa JM, Casas AM (2011) Introgression of an intermediate VRNH1 allele in barley (Hordeum vulgare L.) leads to reduced vernalization requirement without affecting freezing tolerance. Mol Breeding 28: 475-484

Casas AM, Yahiaoui S, Ciudad F, Igartua E (2005) Distribution of MWG699 polymorphism in Spanish European barleys. Genome 48: 41-45

Castro AJ, Hayes P, Viega L, Vales I (2008) Transgressive segregation for phenological traits in barley explained by two major QTL alleles with additivity. Plant Breeding 127: 561-568

Close TJ, Bhat PR, Lonardi S, Wu Y, Wanamaker S, Rostoks N Ramsay L, Stein N, Svensson JT, Bozdag S, Moscou M, Varshney R, Sato K, DeYoung J, Chao S, Waugh R, Marshall D, Graner A, Roose ML, Muehlbauer G, Matthews D, Madishetty K, Fenton RD, Condamine P (2009) Development and implementation of high-throughput SNP genotyping in barley. BMC Genomics 10: 582

Cockram J, White J, Zuluaga DL, Smith D, Comadran J, Macaulay M, Luo Z, Kearsey MJ, Werner P, Harrap D, Tapsell C, Liu H, Hedley PE, Stein N, Schulte D, Steuernagel B, Marshall DF, Thomas WTB, Ramsay L, Mackay I, Balding D, The AGOUEB Consortium, Waugh R, O'Sullivan DM (2011) Genome-wide association mapping to candidate polymorphism resolution in the unsequenced barley genome. Proc Natl Acad Sci USA 107: 21611-21616

Comadran J, Ramsay L, MacKenzie K, Hayes P, Close TJ, Muehlbauer G, Stein N, Waugh R (2011a) Patterns of polymorphism and linkage disequilibrium in cultivated barley. Theor Appl Genet DOI 122: $523-531$

Comadran J, Russell JR, Booth A, Pswarayi A, Ceccarelli S, Grando S, Stanca AM, Pecchioni N, Akar T, Al-Yassin A, Benbelkacem A, Ouabbou H, Bort J, van Eeuwijk FA, Thomas WTB, Romagosa I (2011b) Mixed model association scans of multi-environmental trial data reveal major loci controlling yield and yield related traits in Hordeum vulgare in Mediterranean environments. Theor Appl Genet DOI 10.1007/s00122-011-1537-4

Cuesta-Marcos A, Igartua E, Ciudad FJ, Codesal P, Russell JR, Molina-Cano JL, Moralejo M, Szücs P, Gracia MP, Lasa JM, Casas AM (2008) Heading date QTL in a spring $\mathrm{x}$ winter barley cross evaluated in Mediterranean environments. Mol Breeding 21: 455-471 
Cuesta-Marcos A, Szücs P, Close TJ, Filichkin T, Muehlbauer GJ, Smith KP, Hayes PM (2010) Genomewide SNPs and re-sequencing of growth habit and inflorescence genes in barley: implications for association mapping in germplasm arrays varying in size and structure. BMC Genomics 11: 707

Druka A, Franckowiak J, Lundqvist U, Bonar N, Alexander J, Houston K, Radovic S, Shahinnia F, Vendramin V, Morgante M, Stein N, Waugh R (2011) Genetic dissection of barley morphology and development. Plant Physiol 155: 617-627

Excoffier L, Hofer T, Foll M (2009) Detecting loci under selection in a hierarchically structured population. Heredity 103: 285-298

Excoffier L, Lischer HEL (2010) Arlequin suite ver 3.5: a new series of programs to perform population genetics analyses under Linux and Windows. Mol Ecol Resour 10: 564-567

Gross BL, Olsen KM (2010) Genetic perspectives on crop domestication. Trends Plant Sci 15: 529-537

Harlan JR (1992) Crops \& Man. ASA, CSSA. Madison, Wisconsin.

Hammer K, Lehmann CO, Perrino P (1985) Character variability and evolutionary trends in a barley hybrid swarm - a case study. Biol Zentralblatt 104: 511-517.

Hübner S, Günther T, Flavell A, Fridman E, Graner A, Korol A, Schmid KJ (2012) Islands and streams: clusters and gene flow in wild barley populations from the Levant. Mol Ecol 21: 1115-1129.

Komatsuda T, Maxim P, Senthil N, Mano Y (2004) High-density AFLP map of nonbrittle rachis 1 (btr1) and 2 (btr2) genes in barley (Hordeum vulgare L.). Theor Appl Genet 109: 986-995

Komatsuda T, Pourkheirandish M, He C, Azhaguvel P, Kanamori H, Perovic D, Stein N, Graner A, Wicker T, Tagiri A, Lundqvist U, Fujimura T, Matsuoka M, Matsumoto T, Yano M (2007) Sixrowed barley originated from a mutation in a homeodomain-leucine zipper I-class homeobox gene. Proc Natl Acad Sci USA 104: 1424-1429

Konishi T (2001) Genetic diversity in Hordeum agriocrithon E. Åberg, six-rowed barley with brittle rachis, from Tibet. Genet Res Crop Evol 48: 27-34

Massman J, Cooper B, Horsley R, Neate S, Dill-Macky R, Chao S, Dong Y, Schwarz P, Muehlbauer GJ, Smith KP (2011) Genome-wide association mapping of Fusarium head blight resistance in contemporary barley breeding germplasm. Mol. Breeding 27: 439-454

Molina-Cano JL, Conde J (1980) Hordeum spontaneum C.Koch emend Bacht. collected in Southern Morocco". Barley Genet Newslett 10: 44-47

Molina-Cano JL, Fra-Mon P, Salcedo G, Aragoncillo C, Roca de Togores F, García Olmedo F (1987) Morocco as a possible domestication center for barley. Biochemical and agromorphological evidence. Theor Appl Genet 73: 531-536

Molina-Cano JL, Gómez Campo C, Conde J (1982) Hordeum spontaneum C.Koch as a weed of barley fields in Morocco. Z Pflanzenzücht 88: 161-167

Molina-Cano JL, Igartua E, Casas AM, Moralejo MA (2002) New views on the origin of cultivated barley. In: Slafer GA, Molina-Cano JL, Savin R, Araus JL, Romagosa I (eds) Barley Science: Recent advances from molecular biology to agronomy of yield and quality. The Haworth Press, Binghamton, NY.

Molina-Cano JL, Moralejo M, Igartua E, Romagosa I (1999) Further evidence supporting Morocco as a center of origin of barley. Theor Appl Genet 98: 913-918 
Molina-Cano JL, Russell J, Moralejo MA, Escacena JL, Arias G, Powell W (2005) Chloroplast-DNA microsatellite analysis supports a polyphyletic origin for barley. Theor Appl Genet 110: 613-619

Moragues M, Comadran R, Waugh R, Milne I, Flavell AJ, Russell JR (2010) Effects of ascertainment bias and marker number on estimations of barley diversity from high-throughput SNP genotype data. Theor Appl Genet 120, 1525-1534.

Morrell PL, Clegg MT (2007) Genetic evidence for a second domestication of barley (Hordeum vulgare) east of the Fertile Crescent. Proc Natl Acad Sci USA 104: 3289-3294

Muzzolini A (1989) La "Néolithisation" du Nord de l'Afrique et ses causes. In: Aurenche O, Cauvin J (eds). Néolithisations: Proche et Moyen Orient, Méditerranée orientale, Nord de l'Afrique, Europe méridionale, Chine, Amérique du Sud. Bar International Series 516, pp. 145-186.

Orabi J, Backes G, Wolday A, Yahyaoui A, Jahoor A (2007) The horn of Africa as a center of barley diversification and a potential domestication site. Theor Appl Genet 114: 1117-1127

Orabi J, Jahoor A, Backes G (2009) Genetic diversity and population structure of wild and cultivated barley from West Asia and North Africa. Plant Breeding 128: 606-614

Perrier X, Jacquemoud-Collet JP (2006) DARwin software http://darwin.cirad.fr/darwin

Pourkheirandish M, Komatsuda T (2007) The importance of barley genetics and domestication in a global perspective. Ann Bot 100: 999-1008

Purugganan MD, Fuller DQ (2009) The nature of selection during plant domestication. Nature 457: 843848

Ramsay L, Comadran J, Druka A, Marshall DF, Thomas WTB, Macaulay M, MacKenzie K, Simpson CG, Fuller J, Hayes PM, Lundqvist U, Franckowiak JD, Close TJ, Muehlbauer G, Waugh R (2011) INTERMEDIUM-C, a modifier of lateral spikelet fertility in barley, is an ortholog of the maize domestication gene TEOSINTE BRANCHED 1 Nat Genet 43: 169-173

Rostoks N, Mudie S, Cardle L, Russell J, Ramsay L, Booth A, Svensson JT, Wanamaker SI , Walia H, Rodriguez EM, Hedley PE, Liu H, Morris J, Close TJ, Marshall DF, Waugh R (2005) Genome-wide SNP discovery and linkage analysis in barley based on genes responsive to abiotic stress. Mol Genet Genomics, 274, 515-527.

Russell JR, Dawson IK, Flavell AJ, Steffenson B, Weltzien E, Booth A, Ceccarelli S, Grando S, Waugh R (2011) Analysis of $>1000$ single nucleotide polymorphism in geographically matched samples of landrace and wild barley indicates secondary contact and chromosome-level difference in diversity around domestication genes. New Phytol 191:564-578

Saisho D, Purugganan MD (2007) Molecular phylogeography of domesticated barley traces expansion of agriculture in the Old World. Genetics 177: 1765-1776

Sakuma S, Salomon B, Komatsuda T (2011) The domestication syndrome genes responsible for the major changes in plant form in the Triticeae crops. Plant Cell Physiol doi:10.1093/pcp/pcr025

Salamini F, Özkan H, Brandolini A, Schäffer-Pregl R, Martin W (2002) Genetics and geography of wild cereal domestication in the Near East. Nat Rev Genet 3: 429-441

Sameri M, Takeda K, Komatsuda T (2006) Quantitative trait loci controlling agronomic traits in recombinant inbred lines from a cross of oriental- and occidental-type barley cultivars. Breeding Sci 56: $243-252$ 
Sneath PHA, Sokal RR (1973) Numerical taxonomy. WH Freeman and Company, San Francisco, 573 pp.

Takahashi R (1955) The origin of cultivated barley. Adv Genet 7: 227-266

Taketa S, Yao T, Sakurai Y, Miyake S, Ichii M (2011) Molecular mapping of the short awn 2 (lks2) and dense spike 1 (dsp1) genes on barley chromosome 7H. Breeding Sci 61: 80-85

Tanno K, Taketa S, Takeda K, Komatsuda T (2002) A DNA marker closely linked to the vrs1 locus (rowtype gene) indicates multiple origins of six-rowed cultivated barley (Hordeum vulgare L.). Theor Appl Genet 104: 54-60

Tanno K, Takeda K (2004) On the origin of six-rowed barley with brittle rachis, agriocrithon [Hordeum vulgare ssp. f. agriocrithon (Åberg) Bowd.], based on a DNA marker closely linked to the vrs1 (sixrow gene) locus. Theor Appl Genet 110: 145-150

Trevaskis B (2010) The central role of the VERNALIZATION1 gene in the vernalization response of cereals. Funct Plant Biol 37: 479-487

Weiss E, Kislev ME, Hartmann A (2006) Autonomous cultivation before domestication. Science 312: $1608-1610$

Willcox G (2005) The distribution, natural habitats and availability of wild cereals in relation to their domestication in the Near East: multiple events, multiple centres. Veget Hist Archaeobot 14: 534541

Zohary D (1999) Monophyletic vs. polyphyletic origin of crops on which agriculture was founded in the Near East. Gen Res Crop Evol 46: 133-142 
Table 1. Barley accessions used

\begin{tabular}{cccc} 
Species & Country & $\begin{array}{c}\text { No. of } \\
\text { Accessions }\end{array}$ & Seed source \\
\hline Hordeum vulgare & Morocco & 36 & USDA National Small Grain Collection \\
& Spain* & 7 & Braunschweig Gene Bank \\
& Ethiopia & 16 & USDA National Small Grain Collection \\
Total & Libya & 10 & IPK Gene Bank Gatersleben \\
H. spontaneum & Morocco & 8 & Own collection \\
& Israel & 4 & USDA National Small Grain Collection \\
& Turkey & 2 & USDA National Small Grain Collection \\
& Afghanistan & 4 & USDA National Small Grain Collection \\
& Iran & 4 & USDA National Small Grain Collection \\
& Crete & 1 & Own collection \\
& Libya & 2 & IPK Gene Bank Gatersleben \\
& Cyprus & 1 & Cyprus Agricultural Research Institute \\
H. agriocrithon & Iraq & 2 & USDA National Small Grain Collection \\
\hline Total & Ethiopia & 1 & USDA National Small Grain Collection \\
\hline Grand Total & Tibet & 9 & IPK Gene Bank Gatersleben \\
\hline
\end{tabular}

*Criolla types derived from landraces of Spanish origin brought to South America by the Spanish in the 15$16^{\text {th }}$ centuries. 
Table 2. Analysis of molecular variance (AMOVA) for 103 wild and cultivated barley samples classified into four groups.

\begin{tabular}{lrrlc}
\hline Source of variation & d.f. & $\begin{array}{c}\text { Sums of } \\
\text { squares }\end{array}$ & $\begin{array}{l}\text { Variance } \\
\text { components }\end{array}$ & $\begin{array}{c}\text { Percentage } \\
\text { of variation }\end{array}$ \\
\hline Among populations & 3 & 4617 & $64.3 \mathrm{Va}$ & 42.1 \\
Within populations & 99 & 8775 & $88.6 \mathrm{Vb}$ & 57.9 \\
Total & 102 & 13392 & 153.0 & \\
\hline
\end{tabular}

Fixation Index FST: 0.42 
Table 3. Pairwise comparisons between groups, FST, derived from the analysis of molecular variance (AMOVA).

\begin{tabular}{llll}
\hline & WM & ETH & AGR \\
ETH & 0.517 & & \\
AGR & 0.338 & 0.388 & \\
HSP & 0.424 & 0.562 & 0.240
\end{tabular}




\section{FIGURE CAPTIONS}

Figure 1. Principal component analysis of the accession groupings in a space determined by the three principal axes. Accessions are coloured according to origin: black, Ethiopia; blue, Western Mediterranean cultivated barley; pink, Moroccan H. spontaneum; green, H. agriocrithon; and red, H. spontaneum from countries other than Morocco.

Figure 2. Ward cluster analysis showing the groupings of genotypes. Colours of the accession branches are as in Figure 1.

Figure 3. Selection footprints for three group-to-group comparisons: A) West Mediterranean vs. H. spontaneum, B) Western Mediterranean vs. Ethiopian, and C) H. spontaneum vs. Ethiopian. For each comparison, the lines on top represents the moving means of diversity (heterozygosities, as named in Arlequin), for windows of 21 loci. The lower part of each graph (dotted pattern) shows the moving means of the 21-locus windows for $-\log _{10} \mathrm{P}$ of the probability that the loci have undergone selection.

Supp. Mat. Fig. 1. Neighbour-joining analysis tree of the studied germplasm accessions. 


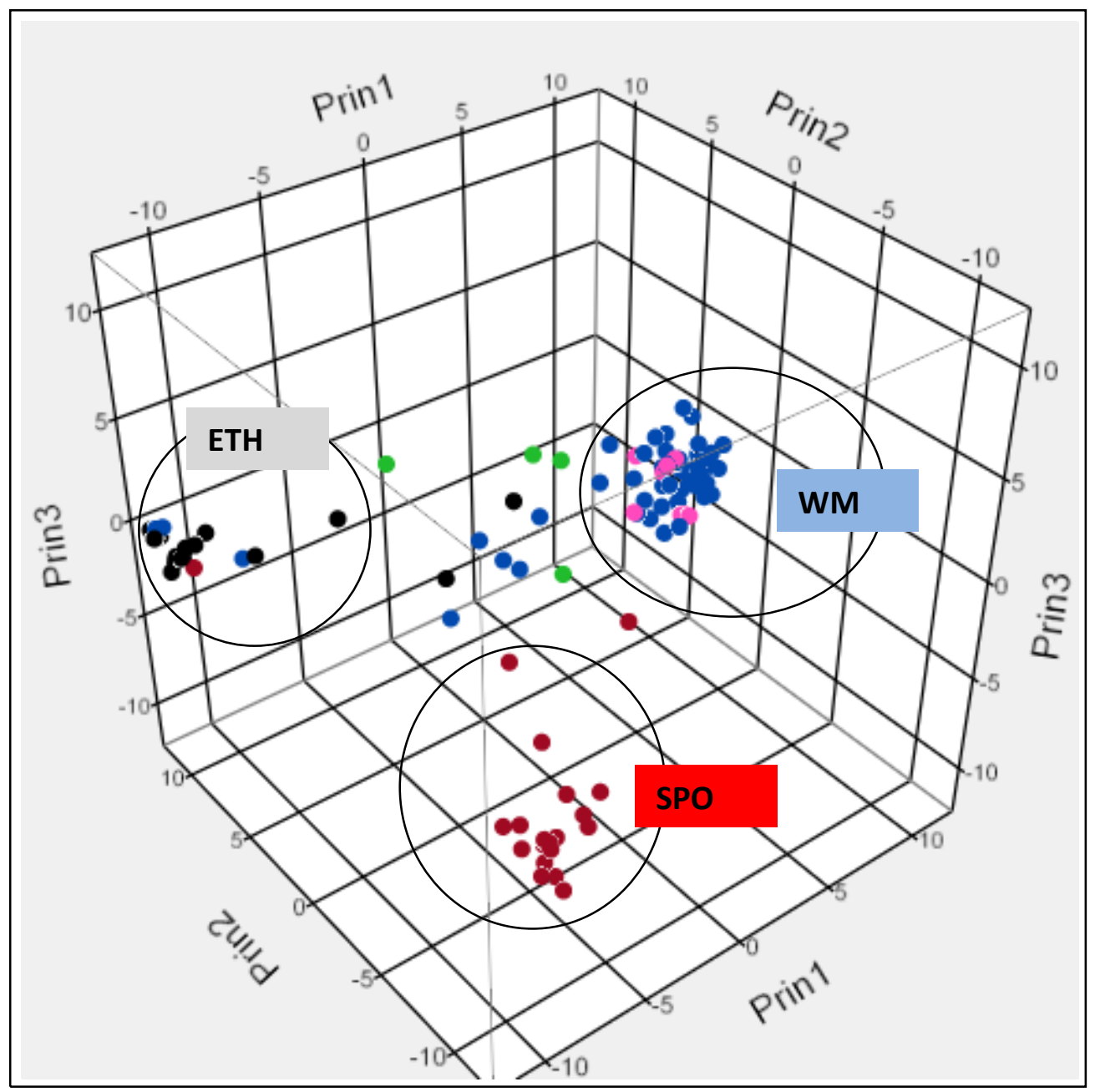




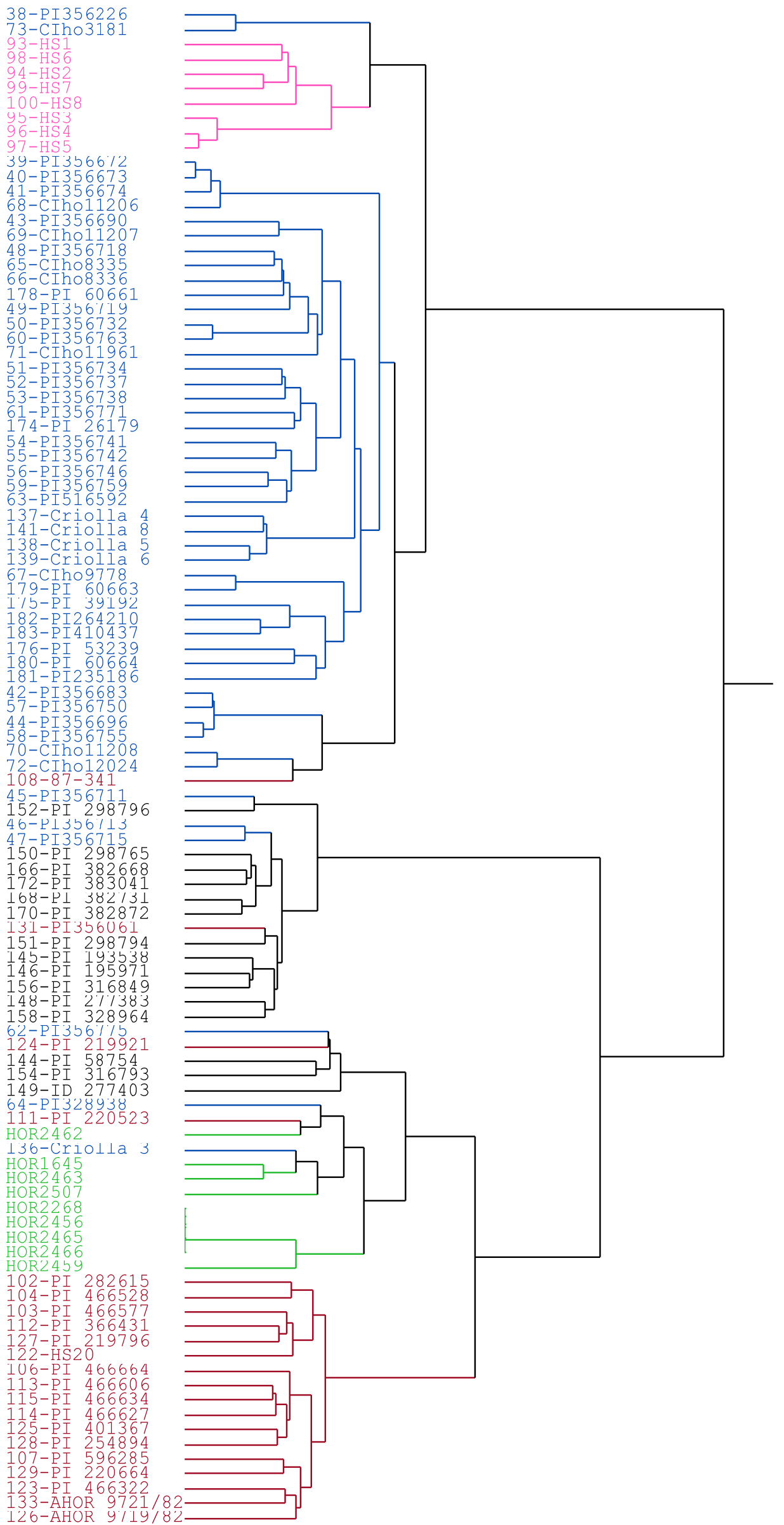



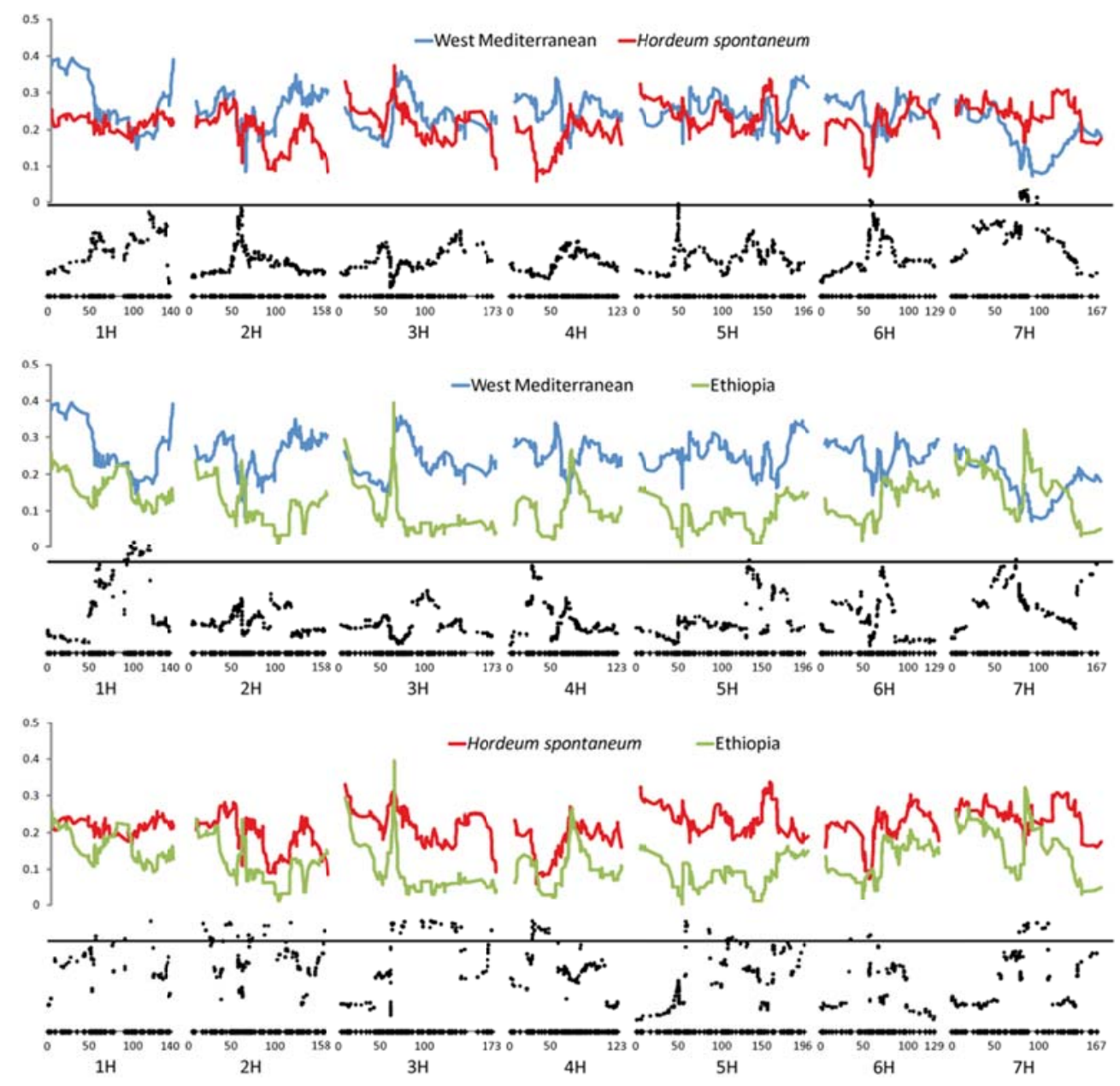


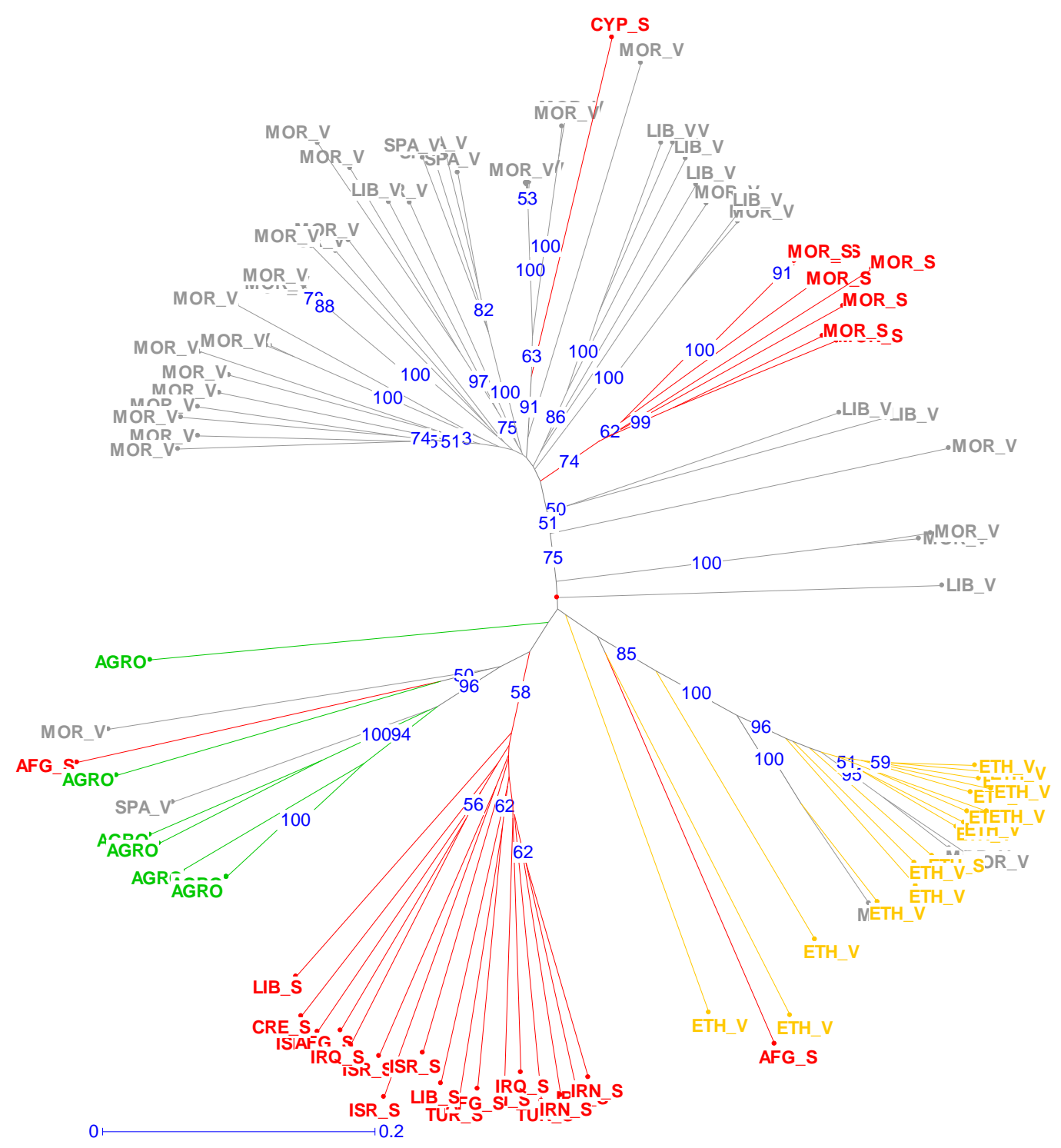


Supplementary material Table 1

Accession

38-PI356226

39-PI356672

40-PI356673

41-PI356674

42-PI356683

43-PI356690

44-PI356696

45-PI356711

46-PI356713

47-PI356715

48-PI356718

49-PI356719

50-PI356732

51-PI356734

52-PI356737

53-PI356738

54-PI356741

55-PI356742

56-PI356746

57-PI356750

58-PI356755

59-PI356759

60-PI356763

61-PI356771

62-PI356775

63-PI516592

64-PI328938

65-CIho8335

66-CIho8336

67-CIho9778

68-CIho11206

69-CIho11207

70-CIho11208

71-CIho11961

72-CIho12024

73-CIho13181

93-HS1

94-HS2

95-HS3

96-HS4

97-HS5

98-HS6

99-HS7

100-HS8
Country

MOR V

MOR V

MOR V

MOR V

MOR_V

MOR V

MOR_V

MOR V

MOR V

MOR V

MOR V

MOR_V

MOR_V

MOR V

MOR_V

MOR V

MOR V

MOR_V

MOR V

MOR_V

MOR V

MOR_V

MOR_V

MOR V

MOR V

MOR V

MOR V

MOR V

MOR V

MOR_V

MOR V

MOR_V

MOR_V

MOR V

MOR V

MOR V

MOR_S

MOR_S

MOR S

MOR_S

MOR S

MOR S

MOR S

MOR_S
Remarks

H. vulgare Morocco

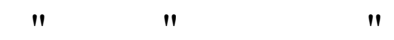

" 11

" 11

" "

" "

" 11

" "

" "

" 11

11

" $"$

" "

" $"$

" " "

" 11

" 11

" "

" "

" $"$

" "

" 11

" 11

" "

" 1

" 11

" "

" 11

" 11

" "

" 11

" "

" 11

" "

" $"$

" " "

H. spontaneum Morocco

$\begin{array}{lll}\text { " } & \text { " } \\ \text { " } & \text { " } \\ " 1 & \text { " } \\ " & \text { " } \\ \text { " } & \text { " } \\ \text { " } & \text { " }\end{array}$




\begin{tabular}{|c|c|c|}
\hline 102-PI 282615 & ISR_S & H. spontaneum Israel \\
\hline 103-PI 466577 & ISR_S & H. spontaneum Israel \\
\hline 104-PI 466528 & ISR_S & H. spontaneum Israel \\
\hline 106-PI 466664 & TUR_S & H. spontaneum Turkey \\
\hline 107-PI 596285 & TUR_S & H. spontaneum Turkey \\
\hline $108-87-341$ & CYP_S & H. spontaneum Cyprus \\
\hline 111-PI 220523 & AFG_S & H. spontaneum Afghanistan \\
\hline 112-PI 366431 & AFG_S & H. spontaneum Afghanistan \\
\hline 113-PI 466606 & IRN_S & H. spontaneum Iran \\
\hline 114-PI 466627 & IRN_S & H. spontaneum Iran \\
\hline 115-PI 466634 & IRN_S & H. spontaneum Iran \\
\hline 122-HS20 & CRE_S & H. spontaneum Crete \\
\hline 123-PI 466322 & ISR_S & H. spontaneum Israel \\
\hline 124-PI 219921 & AFG_S & H. spontaneum Afghanistan \\
\hline 125-PI 401367 & IRN_S & H. spontaneum Iran \\
\hline \multicolumn{3}{|l|}{ 126-AHOR } \\
\hline $9719 / 82$ & LIB_S & H. spontaneum Libya \\
\hline 127-PI 219796 & IRQ_S & H. spontaneum Iraq \\
\hline 128-PI 254894 & IRQ_S & H. spontaneum Iraq \\
\hline 129-PI 220664 & AFG_S & H. spontaneum Afghanistan \\
\hline 131-PI356061 & ETH_S & H. spontaneum Ethiopia \\
\hline \multicolumn{3}{|l|}{ 133-AHOR } \\
\hline $9721 / 82$ & LIB_S & H. spontaneum Libya \\
\hline 136-Criolla 3 & SPA_V & H. vulgare Spain* \\
\hline 137-Criolla 4 & SPA_V & H. vulgare Spain* \\
\hline 138-Criolla 5 & SPA_V & H. vulgare Spain* \\
\hline 139-Criolla 6 & SPA_V & H. vulgare Spain* \\
\hline 140-Criolla 7 & $\mathrm{SPA}_{-}^{-} \mathrm{V}$ & H. vulgare Spain* \\
\hline 141-Criolla 8 & SPA_V & H. vulgare Spain* \\
\hline 143-Criolla 10 & $\mathrm{SPA}_{-}^{-} \mathrm{V}$ & H. vulgare Spain* \\
\hline 144-PI 58754 & ETH_V & H. vulgare Ethiopia \\
\hline 145-PI 193538 & ETH_V & H. vulgare Ethiopia \\
\hline 146-PI 195971 & ETH_V & H. vulgare Ethiopia \\
\hline 148-PI 277383 & ETH_V & H. vulgare Ethiopia \\
\hline 149-ID 277403 & ETH_V & H. vulgare Ethiopia \\
\hline 150-PI 298765 & ETH_V & H. vulgare Ethiopia \\
\hline 151-PI 298794 & ETH_V & H. vulgare Ethiopia \\
\hline 152-PI 298796 & ETH_V & H. vulgare Ethiopia \\
\hline 154-PI 316793 & ETH_V & H. vulgare Ethiopia \\
\hline 156-PI 316849 & ETH_V & H. vulgare Ethiopia \\
\hline 158-PI 328964 & ETH_V & H. vulgare Ethiopia \\
\hline 166-PI 382668 & ETH_V & H. vulgare Ethiopia \\
\hline 168-PI 382731 & ETH_V & H. vulgare Ethiopia \\
\hline 169-PI 382865 & ETH_V & H. vulgare Ethiopia \\
\hline 170-PI 382872 & ETH_V & H. vulgare Ethiopia \\
\hline 172-PI 383041 & ETH_V & H. vulgare Ethiopia \\
\hline 174-PI 26179 & LIB_V & H. vulgare Libya \\
\hline
\end{tabular}




$\begin{array}{lll}\text { 175-PI } 39192 & \text { LIB_V } & \text { H. vulgare Libya } \\ \text { 176-PI 53239 } & \text { LIB_V } & \text { H. vulgare Libya } \\ \text { 177-PI } 60660 & \text { LIB_V } & \text { H. vulgare Libya } \\ \text { 178-PI } 60661 & \text { LIB_V } & \text { H. vulgare Libya } \\ \text { 179-PI } 60663 & \text { LIB_V } & \text { H. vulgare Libya } \\ \text { 180-PI 60664 } & \text { LIB_V } & \text { H. vulgare Libya } \\ \text { 181-PI235186 } & \text { LIB_V } & \text { H. vulgare Libya } \\ \text { 182-PI264210 } & \text { LIB_V } & \text { H. vulgare Libya } \\ \text { 183-PI410437 } & \text { LIB_V } & \text { H. vulgare Libya } \\ \text { HOR1645 } & \text { AGRO } & \text { H. agriocrithon Tibet } \\ \text { HOR2268 } & \text { AGRO } & \text { H. agriocrithon Tibet } \\ \text { HOR2456 } & \text { AGRO } & \text { H. agriocrithon Tibet } \\ \text { HOR2459 } & \text { AGRO } & \text { H. agriocrithon Tibet } \\ \text { HOR2462 } & \text { AGRO } & \text { H. agriocrithon Tibet } \\ \text { HOR2463 } & \text { AGRO } & \text { H. agriocrithon Tibet } \\ \text { HOR2465 } & \text { AGRO } & \text { H. agriocrithon Tibet } \\ \text { HOR2466 } & \text { AGRO } & \text { H. agriocrithon Tibet } \\ \text { HOR2507 } & \text { AGRO } & \text { H. agriocrithon Tibet }\end{array}$

* Landrace of old Spanish origin collected in the Andean region

(Molina-Cano et al

2005) 